Catherine Moon

Boston College

School of Theology and Ministry

\title{
Blood, Blood Everywhere and Not A To Drop Drink: How Jesus' Blood Fulfills the Law
}

Christianity is based in blood and blood is the bearing by which death can never be forgotten. Blood is paradox. For blood is eternal life, it is the ultimate means of reunion with God, and yet blood is also the embodiment of and price for sin. Death permeates it, for the death that enticed its way into all generations did so substantively, corrupting humanity both materially and ontologically, separating humanity from God. In this essay, I will analyze how Jesus' blood fulfills the Law and frees humanity from the chains of sin and death. I will see how blood is understood and portrayed in the covenant of Noah, the covenant of Abraham, and in the Law of Moses, so that the fullness of what it means for God to pour out His blood and die in order that humanity may ultimately live can be fully known.

The story of Noah is not initially based in blood. Instead, Noah begins the world anew alongside the gruesome bloat of flesh, bodies, human and otherwise drying in the wake of God's seven pronged light, their remnant odor growing thick in the air as the rain subsides. Noah bears witness to death, to the fullness of what a nature corrupted begets. He encounters the true significance of existence amidst God's absence. Blood does not explicitly appear in Noah's postdiluvian reality until God establishes this first covenant with Noah and all his descendents, following the flood. By this covenant God promises, "Never again will all life be cut off by the waters of a flood; never again will there be a flood to destroy the earth," and Noah 
agrees "not to eat meat that has its lifeblood still in it," (Genesis 9:4,11). All human beings as descendants of Noah are thus bound by this covenant. But, what is the relationship between not consuming the lifeblood of animals and God promising not to put a swift end to His creation?

This prohibition to not consume animal blood is made in context of God deeming the consumption of all living [and motive] creatures permissible and the shedding of other "men's" blood punishable. In promising not to blot out life, God articulates clear restrictions on how human beings are allowed to take life. In setting out these clear restrictions to humanity, God is spelling out the fact that although human beings do not have dominion over life, they still have the responsibility to uphold the dignity of life. God further states, "for your lifeblood I will surely demand an accounting...And from each man, too, I will demand an accounting for the life of his fellow man" (Genesis 9:5). Here to account for one's blood is to account for one's sins; the purity of one's blood is a reflection of a life's righteousness, the degree to which someone has grown near or has sunk away from God. In making a person's blood accountable to herself and to her fellow man, God is giving humanity the dominion to arbitrate justice on earth, for "whoever sheds the blood of man, by man shall his blood be shed" (Genesis 9:6). However, this covenant is immediately troubling because God says, "Never again will I curse the ground because of man, even though every inclination of his heart is evil from childhood" (Genesis 8:21). This covenant does not keep humanity from sinning or from doing the things for which God flooded the earth originally. Humanity, despite nearly being forever washed away, still has the problem of being inclined towards sin and away from 
God. Humans become responsible for one another's punishments and accolades, but not each other's atonement. The authority over earthly justice God grants humanity appears to exclude salvation.

God establishes a second covenant with Abram, who as a result of this covenant will come to be known as Abraham. This covenant distinguishes itself from Noah's in that it does not bind all human beings, but only Abraham's descendants. God tells Abraham, "My covenant in your flesh is to be an everlasting covenant," (Genesis 17:13). Where Noah receives a prohibitive command, Abraham receives an affirmative one. Where animal blood could not be consumed, since it would leave both a figurative and literal mark of corruption, now Abraham and his descendents must all pour out their own blood, cutting themselves in hopes that circumcision will mark their hearts as well as their flesh. The covenant of circumcision is an everlasting covenant. This is strange because the covenant resides in flesh, which decays and dies, and yet that finite decaying flesh bears within it the infinite and the everlasting. That is why it transcends time and generation. Circumcision is by no means merely external and symbolic. It is an internal motion towards God that first recognizes humanity's corrupt nature and then seeks to transcend it. God tells the Israelites, "Circumcise your hearts," (Deuteronomy 10:16). God's covenant with Abraham and his descendants is meant to move them away from sin and death and bring them toward God and life.

The covenant of circumcision represents God's will to provide for and build up his faithful and obedient servants. This covenant is a way for God's will to make 
its way back into humanity. Those who are born of Adam's seed are born corrupt. Those who are born of circumcision now possess God in a way no other nation has before them. Circumcision points towards humanity's need to be cleansed of its inherited corruption and to be born of God's seed.

This need to be cleansed, so as not to be anymore obstructed from God is further emphasized in the time of Moses, when God gives the Israelites instructions on how to properly conduct a sin offering, saying, "the life of a creature is in the blood, and I have given it to you to make atonement for yourselves on the altar. It is the blood that makes atonement for one's life" (Leviticus 17:11). The sin offering in particular is a way for human beings to confess and acknowledge that the just punishment for sin is death, blood poured out. Any motion away from God is necessarily a motion towards death, no matter the degree or nature of the sin. By the lifeblood of animals, human beings can atone for their sin, but only for a time. Inevitably, this becomes an endless cycle of sacrificing blood for blood, since there is nothing being introduced by the covenant that fully alters that inclination away from evil or frees it from sin. The sin offering is an act of repentance and an appeal to God for restoration from sin. However, the blood of an animal, the blood that may not be consumed is insufficient in lessening the gap between God and humanity. A lower nature does not effect transcendence in a higher nature.

In the Gospel according to Matthew, Jesus sets forth a new covenant with humanity when he says, "Drink from it, all of you. This is my blood of the covenant, which is poured out for many for the forgiveness of sins" (Matthew 26:27-28). This 
new covenant calls for the consumption of his resurrected lifeblood and thereby transforms the sacrificial offering. To not consume lifeblood is the only covenant with God to which all members of the human race are bound and yet, in John's gospel, Jesus says, "My blood is real drink. Whoever eats my flesh and drinks my blood remains in me, and I in him. Just as...I live because of the Father, so the one who feeds on me will live because of me" (John 6:55-58). Jesus is claiming that there is a relationship between consuming his lifeblood and the absolution of sins. Unlike animals' blood, which could never be mixed with man's, Jesus' apparently can be. But, Jesus is not simply pouring out his blood externally on the cross for the atonement of sins like an animal in the sin offering; he is also pouring his blood into man in the ritual memorial of it, cleansing man internally. Yet, even though Jesus takes the place of the animal whose blood is poured out under the Law in a highly ritualized ceremony, Jesus' own sacrifice is not ritualistic, but the result of an unjust execution. It is only through humanity's memorial consumption of Jesus' lifeblood that his sacrifice becomes a sacred ritual.

This further clarifies what the practice of communion and the activity of the Mass effects in human beings according to the piece of human history, which it fulfills, from which it came into being, and in which it forever partakes. For, it is not simply the innocence of Jesus' blood that makes it purifying in the sacred ritual. "Jesus [becomes] the guarantee of a better covenant...because [he] lives forever, he has a permanent priesthood. Therefore, he is able to save completely those who come to God through him, because he always lives to intercede them," (Hebrews 
7:22-25). Where before the new covenant all people were lost to God from sin, now Jesus, immortal, can mediate between God and all human beings.

In conclusion, Jesus, living and resurrected, forgives and reconciles that gap between God and humanity set forth by death. His sacrifice is the ultimate act of love, whereby God becomes humanity's standard for righteousness. For Jesus makes it possible for "the love of God [to be] poured into our hearts by the Holy Spirit which has been given to us" (Romans 5:5). Reconciliation is then the fulfillment of the Law, and the fullness of that reconciliation is love, is humanity's ability not to obey God but to abide in God and to live in accordance with the Spirit. In this way, human beings become accountable for one another's salvation and ultimate reunion with God, because perfect love is now understood to be salvific, and love is that to which each and every human being is called. 